\section{Central banks and civil war termination}

\author{
Ana Carolina Garriga (D) \\ Department of Government, University of Essex (UK). \\ Affiliated professor, Department of Political Studies, CIDE (Mexico)
}

Journal of Peace Research

$1-18$

(C) The Author(s) 2021

(c) (i) (5)

Article reuse guidelines:

sagepub.com/journals-permissions

DOI: $10.1177 / 00223433211038194$

journals.sagepub.com/home/jpr

(SSAGE

\begin{abstract}
The ability to finance conflict likely affects the odds of sustaining a war and succeeding in it. Recent literature explores rebel group funding, but far less is known about how states finance their own war efforts. This article posits that the design of central banks should affect civil war termination. In particular, it argues that central bank independence affects civil war termination through two channels. First, financial markets consider central bank independence as a good signal in terms of macroeconomic stability and debt repayment. In this way, independent central banks enhance the ability of the government to access credit to finance and end a civil war. Second, central bank independence is associated with lower inflation. Inflation control reduces one source of additional grievances that the civil war may impose on citizens. On a sample of civil wars between 1975 and 2009, central bank independence is associated with a substantial increase in the likelihood of war termination. When the form of termination is disaggregated, (higher) central bank independence is associated with a higher probability of government victory, relative to continued conflict and to other outcomes. Additional tests provide support for the argued mechanisms: during civil wars, countries with more independent central banks access international credit markets in better conditions - i.e. they pay lower interest rates, and receive longer grace and maturity periods on new debt. Furthermore, in countries experiencing civil wars, central bank independence is associated with lower inflation.
\end{abstract}

\title{
Keywords
}

central banks, central bank independence, civil war termination, conflict finance, inflation, international finance

\section{Introduction}

The ability to finance conflict likely affects the odds of sustaining a war and succeeding in it. Regarding civil wars, a growing literature shows that rebel group funding has important consequences (Fearon, 2004; Koren \& Bagozzi, 2017; Sawyer, Cunningham \& Reed, 2017; Whitaker, Walsh \& Conrad, 2019), but we know far less about how governments fund their civil war efforts, or the consequences of different forms of financing on civil conflict dynamics. This article focuses on monetary institutions and explains how central banks affect the likelihood and the form of civil war termination.

Civil wars are the most frequent form of large-scale violence (Collier, Hoeffler \& Rohner, 2009). Thus, it is relevant to know whether domestic - in this case, monetary - institutions have the potential to shorten these wars. There is evidence that central banks have important effects on international war finance, and, indirectly, on their outcomes. However, there are reasons to believe that the incentives affecting the relations between central banks, governments, and third parties are different in the context of inter- and intrastate wars. Furthermore, the characteristics of civil wars allow us to test the mechanisms through which central banks affect economic and political outcomes.

When governments face civil wars - as in other instances that threaten their survival - there are incentives to use any tool to survive. In particular, governments at war might want to control monetary institutions to print money as desired. I argue that by restricting the government's access to the printing press to meet immediate needs of war finance, central bank independence does not hamper the ability of governments to end a civil war.

Corresponding author:

carolina.garriga@essex.ac.uk 
Counterintuitively, independence of the central bank strengthens the government in two fronts: it facilitates the governments' access to international financial markets, and it limits the burden of the war on citizens through inflation. This makes war termination, and government victories, more likely.

This article contributes to two literatures. First, it speaks to the literature on conflict finance. This study complements the literature on rebel group funding (Fearon, 2004; Koren \& Bagozzi, 2017; Sawyer, Cunningham \& Reed, 2017; Whitaker, Walsh \& Conrad, 2019), by showing that government finance may also affect civil war outcomes. More specifically, it explains the effect of domestic monetary institutions on civil war dynamics. Although there is a growing literature on the relationship between finance and war (DiGiuseppe, Barry \& Frank, 2012; Slantchev, 2012; Shea, 2014; Shea \& Poast, 2017), the role of central banks during civil wars is underexplored. The few studies of monetary institutions in war times focus on the effects of the existence of central banks - but not on their institutional characteristics - and in the context of interstate wars (Broz, 1998; Poast, 2015). This study builds on this literature, and stresses that civil wars alter both the domestic incentives to use monetary policy, and monetary institutions' international credibility in ways that may differ from international wars. Furthermore, although the creation of central banks had important consequences for war finance, the institutional design and functions of central banks vary significantly across countries and time. I focus on one of the most salient characteristics of central banks, their independence. Finally, no one has looked at how monetary policy might affect war termination. I analyze how differences in central bank independence may affect the ability of the government to finance the war, paving the way to different civil war outcomes.

Second, this research also contributes to the literature on central banking. Results show that central bank independence produces its intended domestic and international effects - namely, inflation control (Cukierman, 1992; Alesina \& Summers, 1993; Bodea \& Hicks, 2015a; Garriga \& Rodriguez, 2020) and access to credit markets (Maxfield, 1997; Bodea \& Hicks, 2015b) even in contexts in which the government's authority is challenged, and in the presence of strong incentives to override this institutional arrangement.

\section{Existing research on financing warfare}

Governments can finance their warfare efforts via taxation, domestic or international borrowing, and inflation (Seligman, 1918; Cappella Zielinski, 2016; Carter \&
Palmer, 2016). ${ }^{1}$ An important literature analyzes why governments choose different strategies to finance international wars. Generally speaking, countries with credibility to borrow can postpone the burden of war costs on their citizens, and countries with lower credit costs are more likely to win their interstate wars (Slantchev, 2012; Shea, 2014, 2016; DiGiuseppe, 2015a, b). Countries with poor reputations need to rely on taxation or inflation (Bordo \& White, 2009).

Research suggests that the very purpose of the first central banks was to finance international wars (Broz, 1998; Poast, 2015). Those central banks worked as commitment devices toward domestic creditors, and enhanced the ability to borrow from domestic banks at lower interest rates, especially during wars (Broz \& Grossman, 2004; Poast, 2015). Although the functions of central banks have evolved, independent central banks have credibilityenhancing effects on international credit markets (Maxfield, 1997; Bodea \& Hicks, 2015b, 2018) that are comparable to adherence to the Gold Standard in the past (Bordo \& Rockoff, 1996).

As I will explain later, the determinants and effects of different types of conflict finance are likely different for intrastate wars. Yet, government finance in civil wars is less studied. Most research on civil war finance focuses on rebel funding, and finds that access to economic resources whether it is natural resources in general (Lujala, 2010), gems and narcotics (Fearon, 2004), remittances (Ballentine \& Sherman, 2003), or third-party support (Sawyer, Cunningham \& Reed, 2017) - make civil wars last longer. Resources allowing longer fights do not necessarily forecast rebel victories (Weinstein, 2005). Regarding the government side, foreign funding, often categorized as interventions', can also lengthen civil wars, in part because it can encourage other funders to support the rebels (Regan, 2002), or because it increases uncertainty regarding the other side's relative strength (Narang, 2015). In contrast, sanctions shorten civil wars and affect the mode of termination (Escribà-Folch, 2010). Overall, rebel-funding types seem important for the outcomes of civil conflicts, but we know less about how state funding - and more specifically, monetary institutions - influence civil wars.

\section{A theory of central bank independence and civil war termination}

Central banks are key institutions for a country's economy. They affect the money supply in the economy,

\footnotetext{
${ }^{1}$ Foreign aid can also help to fund war. However, it depends more on the decision of donors than of the recipients.
} 
either directly, by printing currency, or in more indirect ways, by setting the interest rate or financing fiscal spending. Since their creation, central banks worked as constraints on governments to guarantee the repayment of their debts. Especially in the past decades, the powers and functions of central banks evolved significantly. One of the most important recent developments in central banking is the increased levels of central bank independence. Around the world, most governments insulated central banks from political influence to pursue price stability as their main goal. This development has occurred in democracies and autocracies, in peace times, and in countries experiencing civil wars (Garriga, 2016). In spite of the diffusion of central bank independence, there is significant variance in the levels and timing of reforms.

Extensive research shows that central bank independence has significant economic and political consequences, ranging from inflation control or economic growth (Cukierman, 1992; Alesina \& Summers, 1993; Bodea \& Hicks, 2015a; Garriga \& Rodriguez, 2020) to fiscal spending, regime survival, cabinet stability, and even international wars' dynamics (Broz, 1998; Clark, Golder \& Poast, 2013; Poast, 2015; Bodea \& Higashijima, 2017; Bodea, Garriga \& Higashijima, 2019). Recent work shows robust effects of central bank independence on inflation both in democracies and autocracies (Garriga \& Rodriguez, 2020), and on credit markets (Bodea \& Hicks, 2015b, 2018). This suggests that central bank independence has the potential to affect civil war dynamics.

\section{Central banks and civil war finance}

Why should central banks and their independence affect the dynamics of civil wars? When governments face civil wars, they have incentives to use any tool at their disposal to finance the war. The government's choice depends both on what sources of war finance are available, and on who will suffer (more) the burden of war - different forms of financing impose costs on different domestic groups. The context of civil war may add specific concerns regarding some forms of war finance that are not as salient during interstate war. For example, imposing the costs of war on the population through inflation and taxes may not only reduce support for the war, but also push some citizens to oppose the government (Grossman, 1991, 1995; Easterly \& Fischer, 2001; Kriner, Lechase \& Cappella Zielinski, 2015). These approaches are therefore rather risky during civil war.
Borrowing is another option, as it allows governments to maintain the provision of goods to domestic groups while spending on their war efforts. However, creditors might be less likely to lend to civil war states compared to states involved in interstate war. First, as in the case of international wars, civil wars' effects on the economy may negatively affect the ability to repay the debt (Flandreau \& Flores, 2012; Slantchev, 2012). In civil wars, however, there is an additional concern that if the rebels win the civil war, they might repudiate the debt (Grossman \& Han, 1996; Weidenmier, 2005). ${ }^{2}$ These risks significantly affect not only the costs of borrowing, but the mere access to credit (Grossman \& Han, 1996; Kirshner, 2007; Shea \& Poast, 2017).

Monetary institutions can affect the options available to states for financing war. Depending on their institutional design, central banks can restrain or enable governments to manipulate the economy, which has both domestic and international economic consequences. Restrictive monetary institutions - such as independent central banks - may limit the influence of the governments on the design and application of monetary policy, their access to the central bank lending, and in some cases, even their fiscal spending (Neyapti, 2003; Bodea \& Higashijima, 2017).

I argue that the design of central banks can affect the ability of governments to end civil wars. First, independent central banks are a good signal in international markets that can enhance the country's credibility (Maxfield, 1997; Pastor Jr. \& Maxfield, 1999; Bodea \& Hicks, 2018), allowing governments to borrow to fund their war efforts, and likely improving the odds of governments' victories. Independent central banks can increase the country's credibility in two fronts: in terms of likely debt repayment, and of commitment to inflation control or economic orthodoxy (Bodea \& Hicks, 2018; Garriga \& Meseguer, 2019).

Other policies can work as credibility-enhancing mechanisms. In particular, fixed exchange rates can perform as anti-inflationary commitment devices, but they imply giving up the ability to use monetary policy (Rey, 2015). More importantly, fixed exchange rate regimes are unlikely to affect the ability to repay debt in the future. ${ }^{3}$

Second, independent central banks are associated with lower inflation. This effect is particularly important in

\footnotetext{
${ }^{2}$ Recent examples of debt repudiation a year after a rebel victory are Ghana 1982 and Rwanda 1995 (Armstrong, 2012).

${ }^{3}$ Debt is normally denominated in major currencies. Even if debt was denominated in local currency, countries can change the exchange rate by an administrative act.
} 
countries experiencing civil wars, which tend to have higher levels of inflation (Hamilton, 1977; Kang \& Meernik, 2005). Inflation increases grievances (Grossman, 1991, 1995), and is linked to rebel support (Keen, 2005; Fielding $\&$ Shortland, 2012). ${ }^{4}$ That is why inflation control can reduce one additional source of grievances that civil wars may impose on citizens, and strengthen the government. Although most countries involved in civil wars have weak political institutions, recent research shows that legal central bank independence is effective in context of weak institutions (Neyapti, 2001; Bodea, Garriga \& Higashijima, 2019; Garriga \& Rodriguez, 2020). Furthermore, anecdotal evidence shows that central banks are willing and able to defend their legal prerogatives even in civil wars. For example, the head of the less independent Libyan central bank resisted pressures from both factions in the civil war, refused to resign, maintained the headquarters in Tripoli, and pleaded the bank's neutrality to safeguard Libya's wealth (Kirkpatrick, 2015). In contrast, the dependent Central Bank of Uganda was used by successive governments to finance the civil war (Brownbridge, 1998). Restructured in 2000, the Bank was able to resist political pressures and focus on financial stability and inflation control (Dafe, 2012).

Two caveats apply. First, this argument is not necessarily intuitive: independent central banks may also hamper the government's war financing capabilities. For example, by designing and applying monetary policy insulated from political demands, independent central banks should limit the government's ability to fund spending with inflation (Bodea \& Hicks, 2015a; Garriga \& Rodriguez, 2020), and even curtail fiscal spending (Bodea \& Higashijima, 2017; Bodea, Garriga \& Higashijima, 2019). This could reduce the government's ability to direct resources to the war, and thus extend the war and/ or reduce the likelihood of a government victory. Although several mechanisms may be operating simultaneously, I argue that central bank independence should be associated with better access credit markets to finance the government's war efforts, and with lower inflation that reduces grievances that could incentivize rebels to participate. This should compensate

\footnotetext{
${ }^{4}$ Fielding \& Shortland (2012) argue that inflation's effect on wages exacerbated the government's recruitment and desertion problems in Peru. Keen (2005: 82) links the NPRC's inflation control to its 'waging counterinsurgency "on the cheap"', and inflation escalation to 'increased covert support for the rebels' and young people turning to the rebels (Keen, 2005: 77-79).
}

restrictions on the government's use of monetary policy and of fiscal resources. In fact, these very restrictions should enhance a country's access to international credit markets.

Second, a wide array of domestic and international factors leads to civil war termination. This argument does not suggest that the design of central banks is the main driver of civil war termination, or that central banks use their agency to terminate civil wars. However, holding other things constant, central bank independence allows governments fighting civil wars to finance their war efforts, and to do it in ways that are less taxing on their citizens, which facilitates shorter civil wars, and government victories.

Overall, the possible relationship between central bank independence and civil war outcomes is puzzling. To disentangle these potential divergent effects, I test the following hypothesis:

H1: (Higher) central bank independence increases the likelihood of civil war termination.

If central bank independence improves the government's credibility, this should benefit governments not only in terms of financing war efforts, but also in their ability to negotiate with rebels: rebels, observing that the government has access to funds to sustain the war, may anticipate a likely government's victory and may be more likely to capitulate. However, I argue that central bank independence should primarily affect the government's ability to obtain a military victory over the rebels for the two main reasons mentioned earlier: first, increased credibility allows governments to access credit to finance their warring efforts. Second, inflation control limits (some) costs imposed on the citizens, reducing the negative consequences of inflation in terms of support for the war, and potentially pushing citizens to oppose the government.

H2: (Higher) central bank independence increases the likelihood of government victory.

The following hypotheses test the proposed mechanisms:

H3 (international credibility): Countries experiencing civil wars with (more) independent central banks have better access to international credit markets.

H4 (inflation): (More) independent central banks are associated with lower inflation in countries experiencing civil wars. 


\section{Empirical analysis}

\section{Data and methods}

The sample includes civil wars between 1975 and 2009

(145 government-rebel dyads), as identified in the UCDP dataset (Högbladh, Pettersson \& Themnér, 2011). For Hypothesis 1, the dependent variable is Conflict termination, a dichotomous variable coded 1 if the war ended in a given year, and zero otherwise (data from Sawyer, Cunningham, \& Reed, 2017). To test the effect of central bank independence on different forms of termination (Hypothesis 2), I created a categorical variable using Outcome from Kreutz (2010). The original data includes six categories: government victory, rebel victory, ceasefire, peace agreement, low activity, and actor disappearance. Because the theory does not suggest differences between some of these categories, I recoded the variable to reflect Government Victory, Rebel Victory, Negotiated termination (ceasefire and peace agreement), Other form of termination (low activity and actor disappearance), and Ongoing war.

The main independent variable is central bank independence $(C B I)$, taken from Garriga (2016). $C B I$ is an index that combines 16 legal attributes that affect central bank independence following Cukierman's (1992) criteria. ${ }^{5}$ The index ranges from 0 (minimum) to 1 (maximum). I completed this source by recoding $C B I=0$ for countries without a central bank. For the purposes of this article, coding these observations as zeroes indicates that monetary policy is in the hands of the government.

The baseline specification follows Sawyer, Cunningham, \& Reed (2017) and includes controls for the factions' troop sizes, and a series of dummy variables indicating the parity/superiority of the rebels (Buhaug, 2006), the existence of a legal political wing - data from Sawyer, Cunningham, \& Reed (2017) - and whether the factions receive external support or not (Högbladh, Pettersson \& Themnér, 2011). Economic controls are from the World Bank (2018), and include the country's population, GDP per capita, and oil-exports dependence. Models include Democracy, a dummy variable indicating whether the Polity score is $\geq 6$ (Marshall \& Jaggers, 2012), and the proportion of the territory covered by forest (World Bank, 2018). Finally, I control for the political proximity between the country and the USA (Bailey, Strezhnev \& Voeten, 2017). Online appendix 2

\footnotetext{
5 The index weighs variables coding the appointment and tenure of the bank's governor, the central bank's objectives, its participation in monetary policy, and limitations on lending to the government. Online appendix 1 describes coding rules.
}

shows descriptive statistics and the distribution of the main variables.

To test Hypothesis 1, I estimate panel logistic regressions, instrumental variable probit, and survival analyses. To test Hypothesis 2, I estimate panel multinomial logistic analyses. The inclusion of country- or dyad-fixed effects substantially reduces the sample size and introduces concerns regarding selection bias. Thus, I include regional dummies in main models, but test the robustness of results to other fixed effects.

\section{Central bank independence in the civil war sample}

The study of the effects of central bank independence on a sample of countries experiencing civil war may raise three concerns: First, central banks and reforms in countries experiencing civil wars may differ significantly from those in other countries. Second, civil wars in countries with independent central banks might be qualitatively different from the ones experienced in countries with dependent central banks. Third, governments with better access to funding may be more willing to escalate violence beyond the threshold to code a conflict as civil war, and then win civil wars quickly. ${ }^{6}$

Regarding the first concern, descriptive data suggest that central bank independence does not significantly differ in countries experiencing civil wars. Figure 1 shows levels and reforms to $C B I$ in the world, and in countries experiencing civil wars. The left-side panel in Figure 1 shows the yearly world average of $C B I$ ( 0 minimum, 1 maximum independence), and the average for countries experiencing civil wars. $C B I$ has increased over time around the world, and countries experiencing civil wars have had, on average, slightly lower levels of central bank independence than the world sample. However, this difference is not statistically significant. ${ }^{7}$

Furthermore, the rate of reforms affecting $C B I$ in civil war countries is not significantly different from the worldwide sample's rate: ${ }^{8} 5.70 \%$ and $5.43 \%$ observations in the global and civil war samples experience reforms, respectively. The right-side panel plots the percentage of countries experiencing reforms affecting $C B I$ per year - both for the world and for countries experiencing civil wars. I further disaggregate these reforms by direction ( $C B I$ increases or decreases), in all countries and in countries experiencing civil wars. Figure 2 shows

\footnotetext{
${ }^{6}$ I thank a reviewer and the editor for raising this question.

7 The difference of means of the sample yearly average for countries experiencing (or not) civil wars has $\operatorname{Pr}(|\mathrm{T}|>|\mathrm{t}|)=0.265$.

${ }^{8} \operatorname{Pr}(|\mathrm{T}|>|\mathrm{t}|)=0.962$.
} 

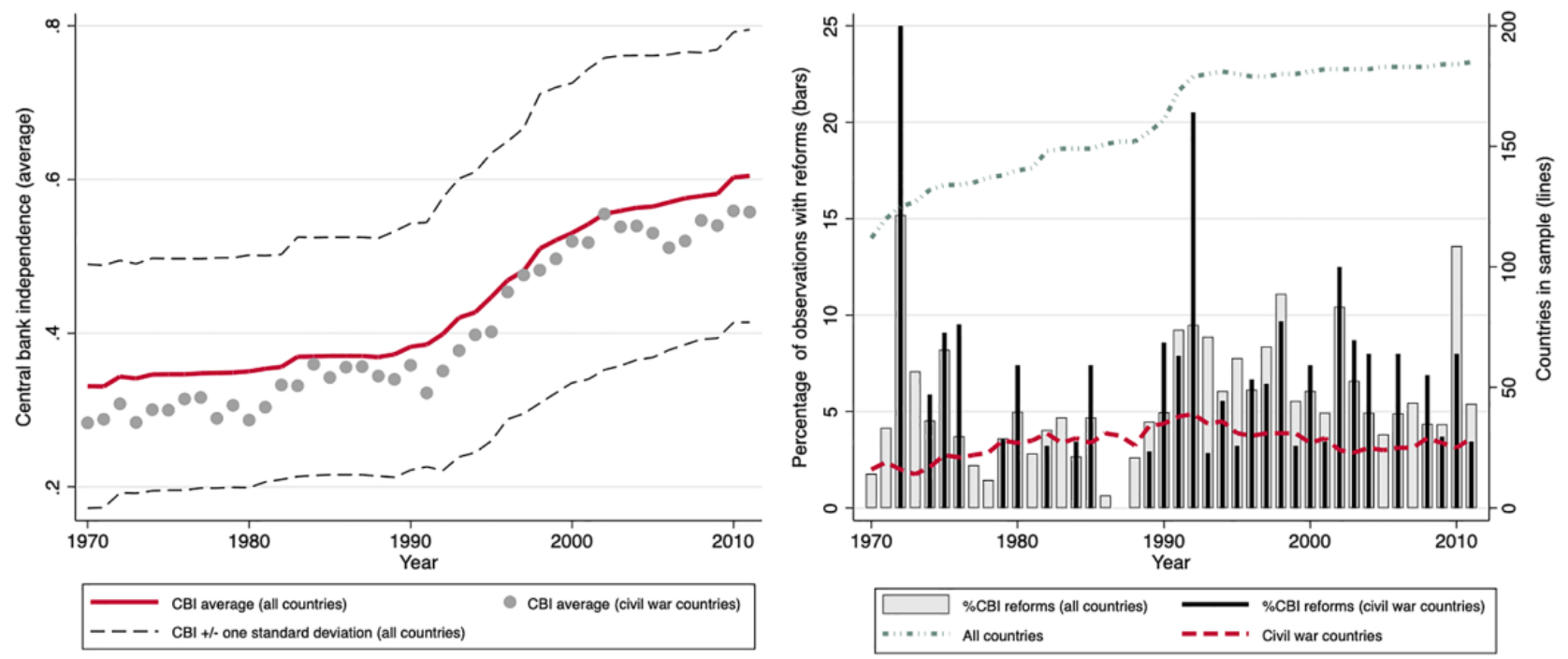

Figure 1. Central bank independence: Average level and reforms in the world, and in countries experiencing civil wars, per year. Data from Garriga (2016) and UCDP (Högbladh, Pettersson \& Themnér, 2011)
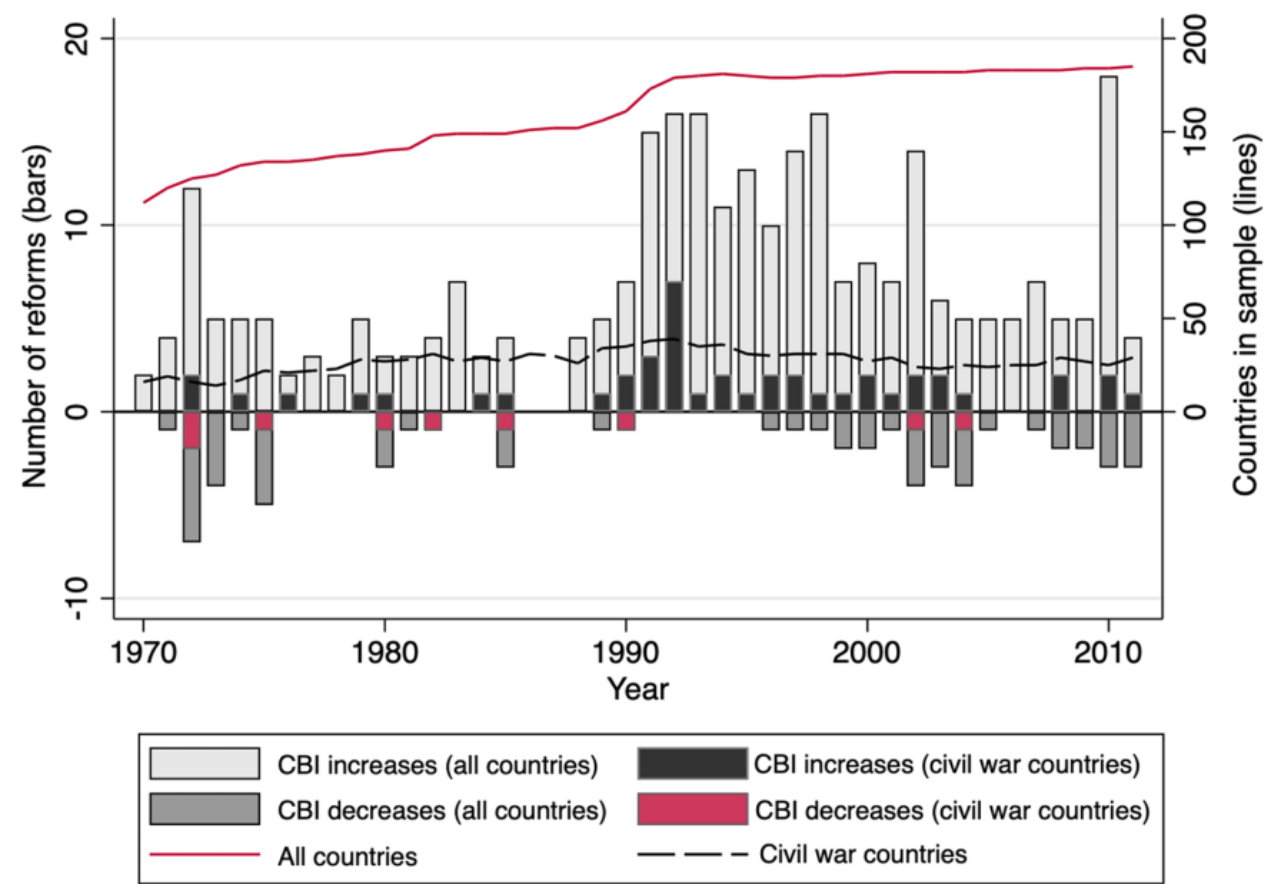

Figure 2. Number of reforms by direction ( $C B I$ increases and decreases) and year, in different samples (civil war and all countries). Data from Garriga (2016) and UCDP (Högbladh, Pettersson \& Themnér, 2011)

that reforms decreasing or increasing $C B I$ are not more prevalent in the civil war subsample.

\footnotetext{
9 In Garriga's (2016) data, the percentage of observations coded as $C B I$ increases between 1970 and 2012 is $4.27 \%$ (3.93\% in the civil war sample). $0.88 \%$ of the worldwide observations are coded as decreases $(0.80 \%$ in the civil war sample).
}

Finally, regarding the timing of reforms affecting $C B I$ and the civil conflict duration, although most observations do not experience reforms, many countries in the sample increased CBI during civil conflict (Algeria, Azerbaijan, Ethiopia, Indonesia, Israel, Nepal, Spain, Thailand, and Turkey), and a few countries reduced $C B I$ during a civil conflict (notably, Indonesia, Sri Lanka, Sudan, and the 
UK). Figure A2.3 (Online appendix 2) plots the yearly level of $C B I$ and reforms per country included in the sample.

Regarding the second concern, descriptive data suggest that civil wars in countries with independent central banks are not significantly different from the ones in countries with dependent central banks. Using data from the first year of the conflict to minimize concerns regarding the effect of my argued mechanism on the data, neither the average number of fatalities, nor the goals of the war (secessionism or control of the government) differ significantly across subsamples of countries with independent and dependent central banks. ${ }^{10}$

Finally, empirical analyses using Cunningham's (2016) data and model specification show that $C B I$ is not significantly associated with civil war onset (Online appendix 3). Although these models have a different unit of analysis (country-year instead of dyad-year), they suggest that $C B I$ does not affect the likelihood of countries escalating conflicts beyond the threshold to be considered as civil wars. ${ }^{11}$

\section{Central bank independence and civil war termination}

Table I shows the test for Hypothesis 1. Model (1) includes $C B I$ and region effects. Models (2) and (3) show the estimates of panel logistic regressions for the baseline model without and with the $C B I$ variable. In models (1) and (3), $C B I$ is positive and statistically significant, suggesting that higher levels of central bank independence are associated with a higher likelihood of conflict termination. The inclusion of $C B I$ does not affect the direction and significance of the control variables: consistent with previous studies, parity or rebel advantage is also associated with a higher probability of war termination. The size of the rebels' troops, the presence of external

\footnotetext{
${ }^{10}$ Using $C B I \geq 0.5$ in the first year to identify independent central banks, the average number of deaths is 22.43 and 15 for countries without and with independent central banks, respectively. The t-test does reject that the difference in means is different from zero $(\operatorname{Pr}(|\mathrm{T}|>|\mathrm{t}|)=0.2165)$. The percentage of secessionist civil wars in each sample is $61 \%$ and $61.4 \%(\operatorname{Pr}(|\mathrm{T}|>|\mathrm{t}|)=0.8291)$.

${ }^{11}$ Given the structure of the data (the unit of analysis country-rebel dyad, year), I cannot directly use a selection model for the main models: A sample for a dyad-year selection model would need to include the universe of dyads experiencing conflict plus all potential dyads that could have escalated into civil wars but have not escalated yet. This would require data on groups of dissidents or rebels that have not used violence yet, or that have used violence without reaching the threshold of victims. This is possibly why, as far as I am aware, no study of civil war termination or severity that uses dyad-year as unit of analysis includes a selection model.
}

support for the rebels, and democracy are associated with a lower likelihood of war termination.

Figure 3 (left-side panel) plots the predictive margins at different levels of $C B I$ after model (3). The plot includes the sample distribution by $C B I$ level. Holding all continuous variables at their mean, and dummies at their median, the probability of a war ending in a given year is 0.115 without central bank $(C B I=0)$, and 0.151 if the central bank is very dependent $(C B I=0.135$, the sample minimum). At the sample maximum $(C B I=$ $0.9)$, the predictive margin is 0.481 . The contrast of the predictive margins is statistically significant at the $99 \%$ level. Although drastic changes from minimum to maximum $C B I$ have not occurred in the sample, these coefficients indicate that the probability of a war ending in a given year more than triplicates if a country moves from the lowest to the highest levels of $C B I$.

To address the concern that countries in a position to end a civil war might be more likely to grant independence to their central banks, I instrument $C B I$ using the lagged average level of $C B I$ in the rest of the world weighted by the inverse of the distance between capital cities, the lagged level of democracy in the neighboring countries, and the legal origin of the country (coded 1 if the country follows the civil law tradition). The distanceweighted world average of $C B I$ is a satisfactory instrument because there is evidence that one of the main predictors of $C B I$ is diffusion (Bodea \& Hicks, $2015 b$ ); it is correlated with a country's $C B I$, but it is unlikely to affect a country's likelihood to end an ongoing civil war. Neighboring countries' average democracy and legal origin are also associated with $C B I$, but they are not associated with the dependent variable. $^{12}$ The results of this analysis (model (4)) are consistent with the main model. The right-side panel in Figure 3 plots the marginal effect of the instrumented $C B I$ variable. In this estimation, the predicted probability of a war termination is 0.07 when $C B I$ is zero, and 0.32 when $C B I$ equals 0.9 (holding dichotomous variables at their median and continuous variables at their mean).

Finally, a Cox regression analysis also supports Hypothesis 1 (see model (5)). ${ }^{13}$ Holding other factors

12 The instruments are positive and significantly associated with $C B I$. The Wald test does not reject the hypothesis that the instruments are exogenous (Prob $>$ chi $2=0.59$ ).

${ }^{13}$ Because some governments are involved in more than one conflict at the same time (several dyads), these models account for shared frailty at the country level (Andersen et al., 1997). I thus interact the continuous measure with the log of time as in Licht (2011). 
Table I. Estimates of conflict termination. Different estimation techniques

\begin{tabular}{|c|c|c|c|c|c|c|c|}
\hline \multirow{2}{*}{ Model } & \multirow{2}{*}{$\begin{array}{c}\text { (1) } \\
\text { Panel logit }\end{array}$} & \multirow{2}{*}{$\begin{array}{c}\text { (2) } \\
\text { Panel logit }\end{array}$} & \multirow{2}{*}{$\begin{array}{c}\text { (3) } \\
\text { Panel logit }\end{array}$} & \multicolumn{2}{|c|}{ (4) } & \multicolumn{2}{|c|}{ (5) } \\
\hline & & & & $I V_{t}$ & robit & Cox regr & $\operatorname{ssion}(\$)$ \\
\hline Estimation & & & & & First stage & & \\
\hline$C B I$ & $\begin{array}{l}2.600^{* * *} \\
(0.767)\end{array}$ & & $\begin{array}{l}2.681^{* * *} \\
(0.763)\end{array}$ & $\begin{array}{c}1.570^{*} \\
(0.620)\end{array}$ & & $\begin{array}{c}6.254^{*} \\
(5.231)\end{array}$ & $+525 \%$ \\
\hline Troop size, govt $(\ln )$ & & $\begin{array}{c}0.0167 \\
(0.122)\end{array}$ & $\begin{array}{c}0.0539 \\
(0.125)\end{array}$ & $\begin{array}{c}0.0663 \\
(0.0614)\end{array}$ & $\begin{array}{c}-0.0100 \\
(0.0116)\end{array}$ & $\begin{array}{l}0.967 \\
(0.0970)\end{array}$ & \\
\hline Troop size, rebel $(\ln )$ & & $\begin{array}{r}-0.248^{* *} \\
(0.0862)\end{array}$ & $\begin{array}{r}-0.246^{* *} \\
(0.0882)\end{array}$ & $\begin{array}{c}-0.158^{*} \\
(0.0638)\end{array}$ & $\begin{array}{r}-0.00767 \\
(0.00589)\end{array}$ & $\begin{array}{r}0.800^{* *} \\
(0.0573)\end{array}$ & $-20 \%$ \\
\hline Legal political wing & & $\begin{array}{c}0.454 \\
(0.453)\end{array}$ & $\begin{array}{c}0.596 \\
(0.457)\end{array}$ & $\begin{array}{c}0.184 \\
(0.247)\end{array}$ & $\begin{array}{c}-0.0564 \\
(0.0447)\end{array}$ & $\begin{array}{c}1.777^{\dagger} \\
(0.571)\end{array}$ & $+78 \%$ \\
\hline Parity/rebel advantage & & $\begin{array}{c}1.010^{\dagger} \\
(0.604)\end{array}$ & $\begin{array}{c}1.398^{*} \\
(0.642)\end{array}$ & $\begin{array}{l}1.181^{* * *} \\
(0.281)\end{array}$ & $\begin{array}{c}-0.203^{*} \\
(0.0878)\end{array}$ & $\begin{array}{l}3.609^{* *} \\
(1.633)\end{array}$ & $+261 \%$ \\
\hline External support, govt & & $\begin{array}{c}-0.211 \\
(0.284)\end{array}$ & $\begin{array}{c}-0.396 \\
(0.295)\end{array}$ & $\begin{array}{c}-0.265 \\
(0.161)\end{array}$ & $\begin{array}{c}0.0323 \\
(0.0481)\end{array}$ & $\begin{array}{c}0.693 \\
(0.161)\end{array}$ & \\
\hline External support, rebel & & $\begin{array}{c}-0.937^{* * *} \\
(0.262)\end{array}$ & $\begin{array}{c}-0.831^{* *} \\
(0.266)\end{array}$ & $\begin{array}{c}-0.383^{*} \\
(0.172)\end{array}$ & $\begin{array}{r}-0.0599^{\dagger} \\
(0.0340)\end{array}$ & $\begin{array}{c}0.645^{*} \\
(0.135)\end{array}$ & $-35 \%$ \\
\hline GDP per capita $(\ln )$ & & $\begin{array}{c}0.139 \\
(0.179)\end{array}$ & $\begin{array}{c}0.159 \\
(0.184)\end{array}$ & $\begin{array}{c}0.0863 \\
(0.109)\end{array}$ & $\begin{array}{c}-0.0695^{* *} \\
(0.0269)\end{array}$ & $\begin{array}{c}1.274 \\
(0.219)\end{array}$ & \\
\hline Democracy & & $\begin{array}{c}-0.769^{\dagger} \\
(0.418)\end{array}$ & $\begin{array}{c}-1.107^{*} \\
(0.440)\end{array}$ & $\begin{array}{c}-0.456 \\
(0.317)\end{array}$ & $\begin{array}{c}0.0895^{*} \\
(0.0404)\end{array}$ & $\begin{array}{c}0.496^{*} \\
(0.171)\end{array}$ & $-50 \%$ \\
\hline Population (ln) & & $\begin{array}{c}-0.142 \\
(0.163)\end{array}$ & $\begin{array}{c}-0.132 \\
(0.167)\end{array}$ & $\begin{array}{l}-0.102 \\
(0.0758)\end{array}$ & $\begin{array}{c}-0.00720 \\
(0.0258)\end{array}$ & $\begin{array}{c}0.931 \\
(0.139)\end{array}$ & \\
\hline Oil & & $\begin{array}{c}-0.579 \\
(0.521)\end{array}$ & $\begin{array}{c}-0.735 \\
(0.533)\end{array}$ & $\begin{array}{c}0.147 \\
(0.335)\end{array}$ & $\begin{array}{c}0.0381 \\
(0.0736)\end{array}$ & $\begin{array}{c}0.429^{\dagger} \\
(0.187)\end{array}$ & $-57 \%$ \\
\hline Forest & & $\begin{array}{c}0.0389 \\
(0.161)\end{array}$ & $\begin{array}{l}0.0606 \\
(0.162)\end{array}$ & $\begin{array}{c}0.0247 \\
(0.0961)\end{array}$ & $\begin{array}{c}0.0189 \\
(0.0247)\end{array}$ & $\begin{array}{c}0.883 \\
(0.129)\end{array}$ & \\
\hline Affinity with USA & & $\begin{array}{l}-1.103 \\
(1.041)\end{array}$ & $\begin{array}{l}-0.572 \\
(1.059)\end{array}$ & $\begin{array}{l}-0.126 \\
(0.561)\end{array}$ & $\begin{array}{l}-0.155 \\
(0.139)\end{array}$ & $\begin{array}{c}0.138^{*} \\
(0.124)\end{array}$ & $-86 \%$ \\
\hline Instruments: & & & & & & & \\
\hline $\begin{array}{l}\text { Weighted world CBI } \\
\text { Average }{ }_{\mathrm{t}-1} \\
\text { Neighbors' average } \\
\text { Democracy } \mathrm{t}-1 \\
\text { Legal origin }\end{array}$ & & & & & $\begin{array}{c}2,287^{* *} \\
(620.9) \\
0.0250^{* *} \\
(0.00745) \\
0.142^{* *} \\
(0.0440)\end{array}$ & & \\
\hline $\operatorname{Ln}(t)$ & & & & & & $\begin{array}{l}0.492^{* *} \\
(0.111)\end{array}$ & $-51 \%$ \\
\hline$C B I^{*} \ln (\mathrm{t})$ & & & & & & $\begin{array}{l}1.111 \\
(0.500)\end{array}$ & \\
\hline Constant & $\begin{array}{l}-0.833 \\
(0.508)\end{array}$ & $\begin{array}{c}1.691 \\
(3.228)\end{array}$ & $\begin{array}{c}4.113 \\
(3.089)\end{array}$ & $\begin{array}{l}0.561 \\
(2.109)\end{array}$ & $\begin{array}{l}1.029^{*} \\
(0.465)\end{array}$ & & \\
\hline Observations/subjects & 708 & 708 & 708 & 673 & 673 & 708 & \\
\hline Dyads & 145 & 145 & 145 & 135 & 135 & 145 & \\
\hline No. of failures & & & & & & 153 & \\
\hline Region FE & YES & YES & YES & YES & YES & YES & \\
\hline McKelvey\&Zavoina's $\mathrm{R}^{2}$ & 0.1428 & 0.1294 & 0.1749 & & & & \\
\hline $\begin{array}{l}\text { Wald } \text { chi }^{2} / \mathrm{Chi}^{2} \\
\text { Wald Test of Exogeneity ( } p \text { value) }\end{array}$ & 19.48 & 39.19 & 47.46 & $\begin{array}{r}83.78 \\
0.5941\end{array}$ & & 131.97 & \\
\hline
\end{tabular}

Statistical significance indicated as follows: ${ }^{* * *} \mathrm{p}<0.001,{ }^{* *} \mathrm{p}<0.01,{ }^{*} \mathrm{p}<0.05,{ }^{\dagger} \mathrm{p}<0.1$. Robust standard errors in parentheses.

$(\S)$ Cox regression. Breslow method for ties. Gamma shared frailty (cowcode). Coefficients and standard errors are exponentiated (seEform). 

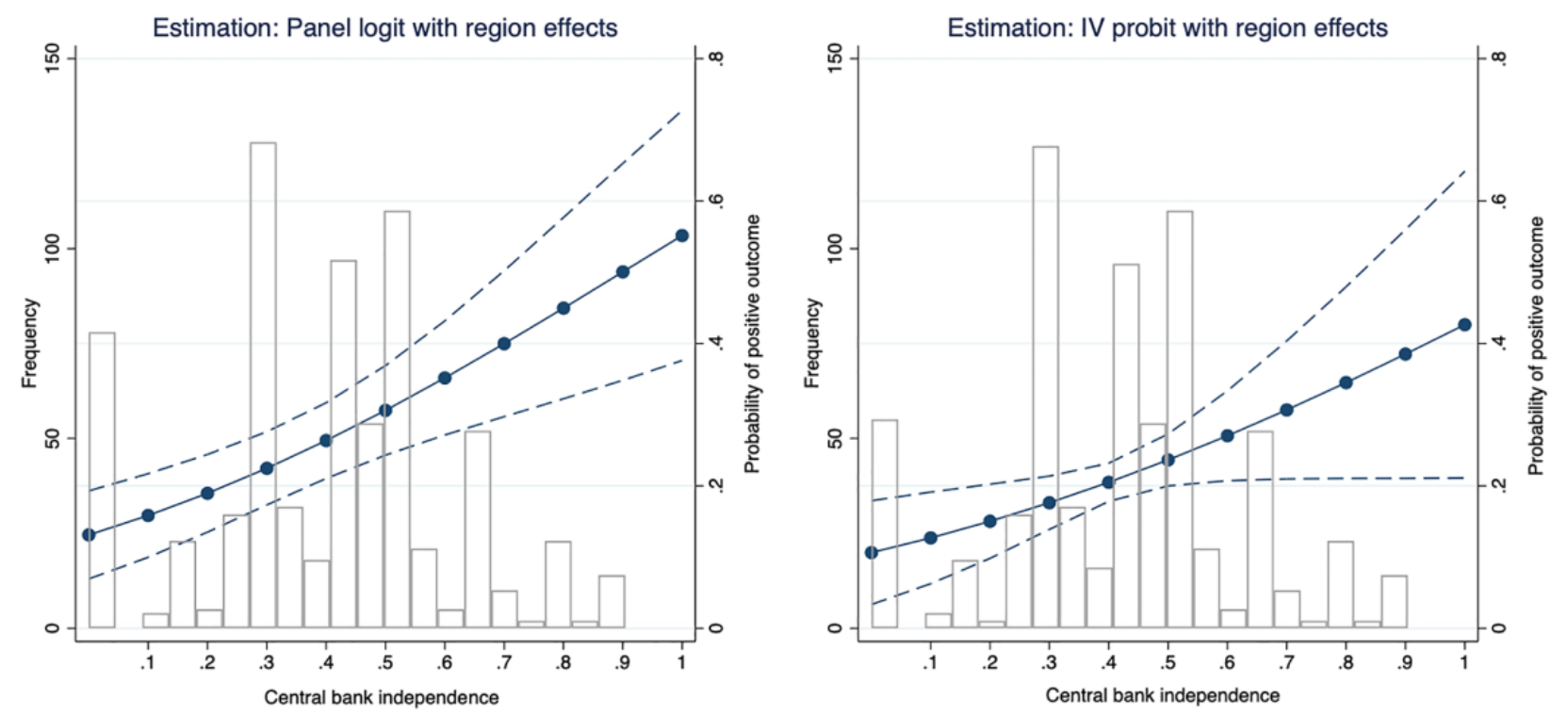

Predictive margins with $95 \% \mathrm{Cl}$

Figure 3. Probability of End of Conflict at different levels of CBI. Different estimation techniques

constant, a conflict (government-rebel dyad) in a country with a fully independent central bank has a $525 \%$ higher risk to end in a given year, compared to a conflict in a country without a central bank. No country moved from scoring 0 to 1 in the $C B I$ index. However, a standard deviation increase in $C B I(0.209)$ is associated with a $46.7 \%$ increase in the risk of ending in a given year. ${ }^{14}$ The existence of a legal political wing, and parity or rebel advantage also statistically significantly increase the risk of war termination. Larger rebel troops, external support for the rebels, democracy, the existence of democracy, oil production, and affinity with the USA reduce the risk of wars ending in a given year. Figure 4 shows the proportional hazards ratios at different levels of $C B I$ (the sample maximum and minimum, and at the 0.5 cut-off point, normally used to indicate an independent central bank). Overall, these analyses provide support to the hypothesis stating that central bank independence is associated with a higher likelihood of war termination.

\section{Robustness checks}

The results reported in this article are robust to different estimation techniques, different measure of the dependent variable, and the inclusion of additional controls. All tables are in Online appendix 4.

\footnotetext{
${ }^{14}$ The effect of a standard deviation is the coefficient exponentiated $\left[(6.254)^{\wedge} 0.209=1.467\right)$.
}

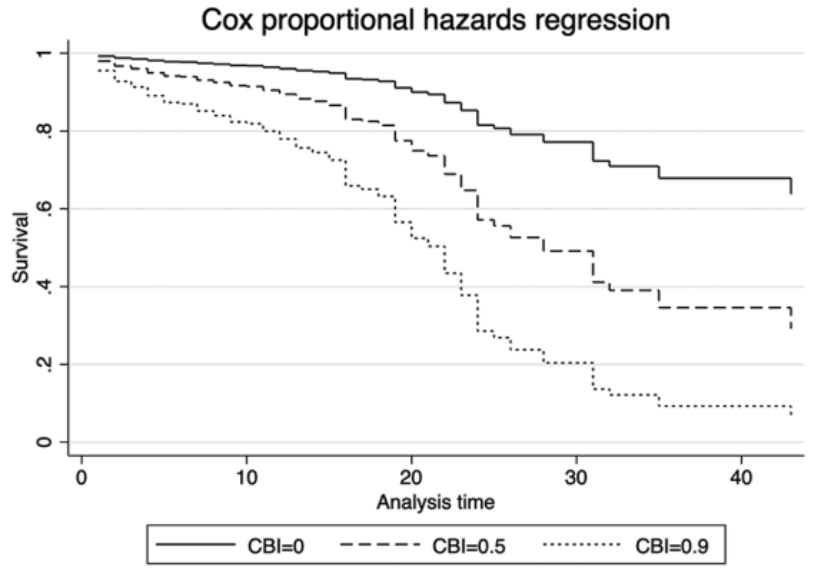

Figure 4. Hazards ratios at different levels of central bank independence

First, the literature on civil war termination normally uses pooled logistic analysis with clustered errors. Results hold using this technique (top left panel, Figure 5). I obtain similar results if I dichotomize $C B I$, coded 1 if $C B I \geq 0.5$, and zero otherwise (top center panel, Figure 5). In these models, the probability of a war ending in a given year is 0.20 if the central bank is not independent. When the central bank is independent, the predictive margin is 0.41 .

To reduce concerns regarding the case of countries that, in view that they are losing the war, might reduce the independence of their central banks, I replace the current levels of $C B I$ for the level of $C B I$ the year before the conflict initiated. Results hold (top-right panel). 


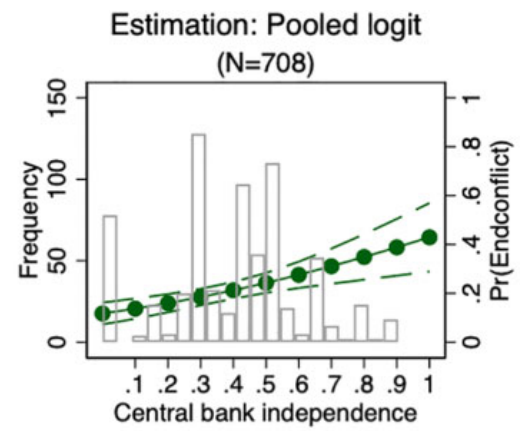

Additional control: Tax capacity $(\mathrm{N}=384)$

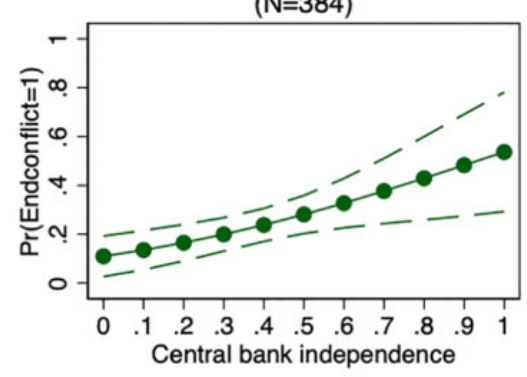

Additional control: Decade dummies

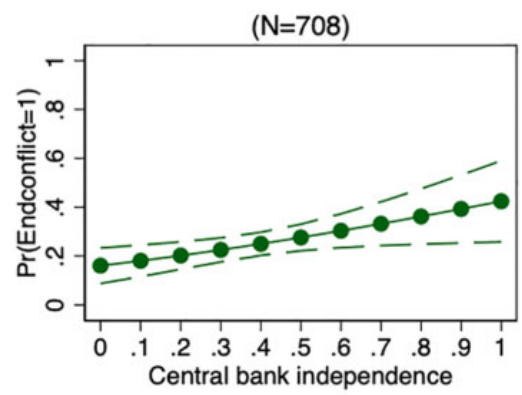

Dichotomous $\mathrm{CBI}$

$(\mathrm{N}=708)$

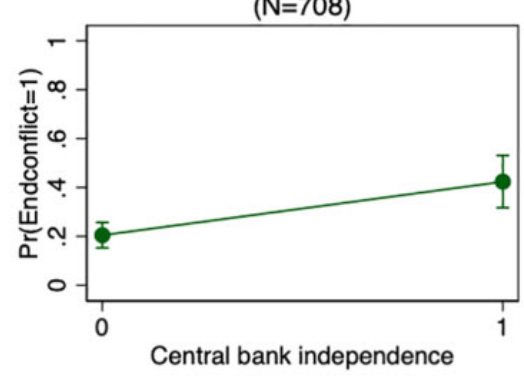

Additional control: Military expenditure $(\mathrm{N}=623)$

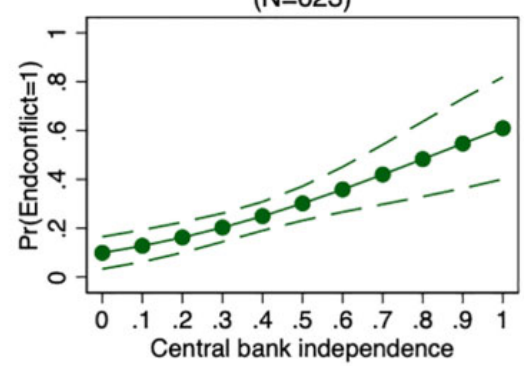

Additional control: Year dummies

$(\mathrm{N}=611)$

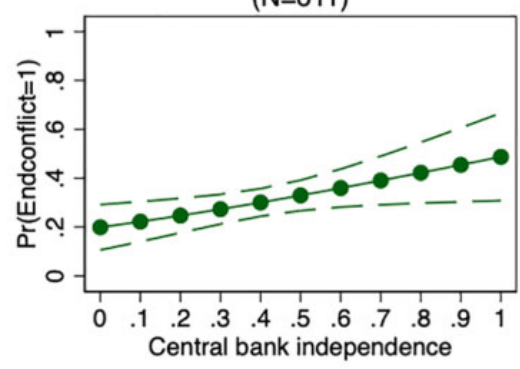

Pre-civil war $\mathrm{CBI}$

$(\mathrm{N}=543)$

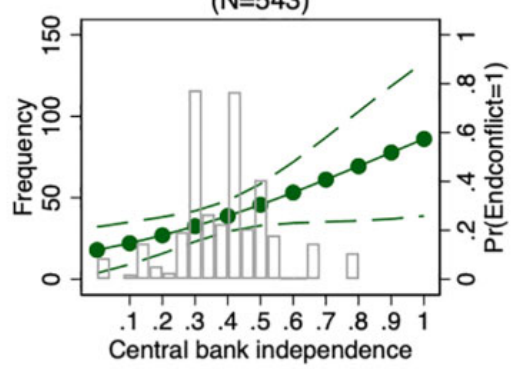

Additional control: Defense expenditure $(\mathrm{N}=482)$

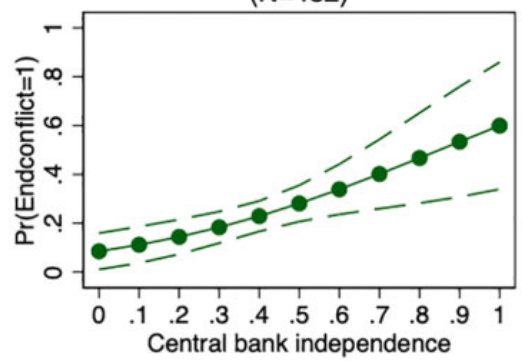

Predictive margins with $95 \% \mathrm{Cl}$

Figure 5. Marginal effect of CBI on End of Conflict. Robustness checks

The instrumental variable analysis addressed the concern of potential endogeneity of central bank independence to the ability to end a civil war. This may not dissipate concerns regarding the independence of $C B I$ from state capacity. Although the literature and descriptive data suggest that central bank independence may be orthogonal to state capacity, ${ }^{15}$ it is possible that countries

\footnotetext{
${ }^{15}$ Research shows that $C B I$ does not necessarily correlate with institutional quality (Bodea, Garriga \& Higashijima, 2019; Baerg, Gray \& Willisch, 2020; Garriga \& Rodriguez, 2020). Furthermore, descriptive data suggest that $C B I$ may be orthogonal to state capacity. Many countries with high state capacity have independent central banks. However, many countries with low state capacity delegate monetary policy to technocrats because of their own inability to conduct monetary policy, or because of international pressures for
}

with high state capacity are more likely to both delegate monetary policy, and also end civil wars faster than countries with low state capacity. I test the robustness of these results to the inclusion of state capacity. I decompose state capacity into two dimensions that can be related to the ability of a government to end a civil war: bureaucratic/administrative capacity, and military capacity (Hendrix \& Young, 2014). To proxy

reform (Maxfield, 1997; Polillo \& Guillén, 2005; Bodea \& Hicks, 2015a). Empirically, some countries scoring high in state capacity proxies have or had low CBI (UK, Israel, or South Africa), and others have high $C B I$. Conversely, some low-capacity states have independent central banks (Nigeria), whereas others have dependent central banks (Bangladesh). 
Table II. Estimates of form of termination. Multinomial logistic regression of civil war outcome

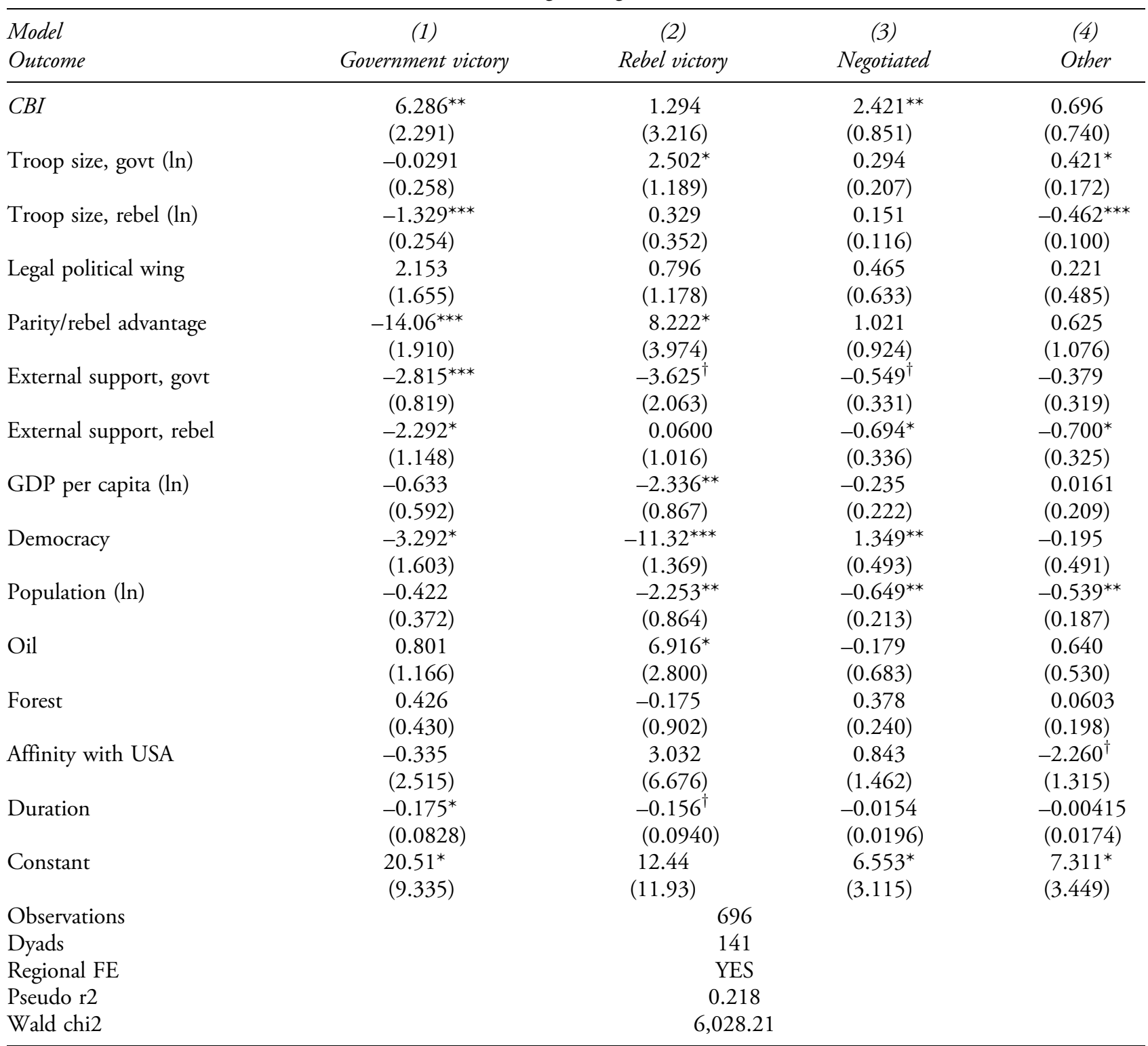

Statistical significance indicated as follows: ${ }^{* * *} \mathrm{p}<0.001,{ }^{* *} \mathrm{p}<0.01,{ }^{*} \mathrm{p}<0.05,{ }^{\dagger} \mathrm{p}<0.1$.

bureaucratic/administrative capacity, I include Tax capacity, the log of the total tax share as a percentage of GDP (Hendrix, 2010). To proxy military capacity, I include military expenditure as a percentage of the GDP, in logs (Military expenditure) - data from World Bank (2018) - and Defense expenditure, the log of the ratio of national defense expenditure to total national expenditure (Banks \& Wilson, 2016). Data missingness significantly reduces the sample (models lose between $12 \%$ and $46 \%$ of the observations). None of the controls for state capacity achieves statistical significance in models excluding and including $C B I$. The coefficient associated with $C B I$, and the predictive margins, remain positive and statistically significant. See marginal effects in Figure 5.

Results are robust to the inclusion of different measures of sanctions from Escribà-Folch (2010) (Table A4.2), to the use of different fixed effects (I replace region-fixed effects with dyad-fixed effects, ${ }^{16}$ and decade-fixed effects with year-fixed effects), and to the re-estimation of the baseline model using Cook, Hays \& Franzese's (2020) penalized solution for fixed effects in rare events data (Table A4.3). To address concerns

\footnotetext{
${ }^{16}$ Models including country-fixed effects do not converge. When forced to converge, results are similar to the main models.
} 

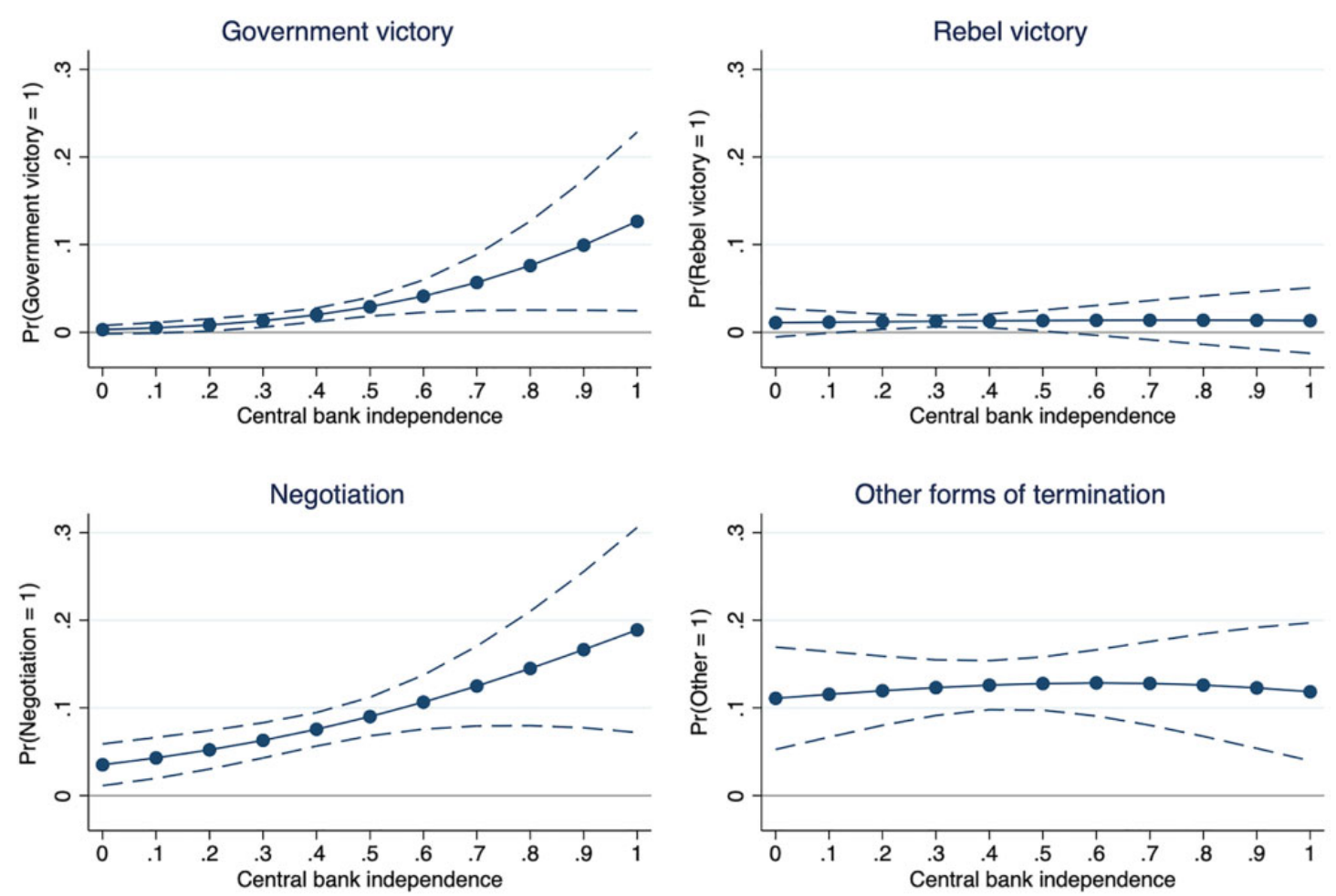

Predictive margins with $95 \% \mathrm{Cl}$

Figure 6. Predictive margins for each form of termination, after multinomial logistic regression

regarding eventual spuriousness of correlations among trended time-series, or a post-Cold War shift that is both affecting $C B I$ and the duration of civil wars, I run models including additional controls for trend, years 1989 and 1990, Cold War, and in subsamples before and after the end of the Cold War, with and without Trend (Table A4.4), and including Duration of the civil war (Table A4.5).

\section{Disaggregating the form of termination}

Hypothesis 2 suggests that central bank independence should be associated with a higher probability of a government victory. Table II presents the estimates of a panel multinomial logistic regression for Government victory, Rebel victory, Negotiated termination (including ceasefire and peace agreement), and Other forms of termination (including low activity and actor disappearance). The baseline outcome is ongoing war. Figure 6 plots the predictive margins at different levels of $C B I$.

Central bank independence is significantly associated with a higher likelihood of government victory. Substantively, the average predicted probability of war ending in a government victory in a given year is 0.007 in a country with a dependent central bank $(C B I=$ 0.16 ), but it is 0.1 if the country has a very independent central bank $(C B I=0.9) .{ }^{17}$ These estimates are significant at $95 \%$ and provide support to Hypothesis 2 . If the continuous measure of $C B I$ is replaced by the dichotomous measure, results are similar: the probability of a conflict ending in a government victory is 0.01 if the central bank is dependent, and 0.05 if it is independent. Tables and plots in Online appendix 5.

Table II suggests that central bank independence is also positively associated with the likelihood of observing a negotiated agreement: the likelihood of this form of termination is 0.075 on average, but 0.035 and 0.16 at the maximum and minimum levels of $C B I(C B I=0$ and .9, respectively). This result suggests that central bank independence may benefit governments not only in terms of financing war efforts, but also in their ability to negotiate with rebels. However, this result is not robust to the use of the dichotomous measure for $C B I$.

\footnotetext{
17 The average predicted probability of observing a government victory in a given year is 0.003 .
} 
Table III. Access to international credit. New external debt commitments' average interest, grace period and maturity

\begin{tabular}{|c|c|c|c|c|c|c|}
\hline $\begin{array}{l}\text { Model } \\
\text { Dependent variable }\end{array}$ & $\begin{array}{c}\text { (1) } \\
\text { Interest rate }\end{array}$ & $\begin{array}{c}\text { (2) } \\
\text { Interest rate }\end{array}$ & $\begin{array}{l}\text { (3) } \\
\text { Grace period }\end{array}$ & $\begin{array}{c}\text { (4) } \\
\text { Grace period }\end{array}$ & $\begin{array}{c}\text { (5) } \\
\text { Maturity }\end{array}$ & $\begin{array}{c}\text { (6) } \\
\text { Maturity }\end{array}$ \\
\hline$C B I$ & $\begin{array}{l}-5.464^{* * *} \\
(0.538)\end{array}$ & $\begin{array}{l}-2.524^{* * *} \\
(0.645)\end{array}$ & $\begin{array}{l}7.851^{* * *} \\
(0.867)\end{array}$ & $\begin{array}{l}5.298^{* * *} \\
(1.088)\end{array}$ & $\begin{array}{l}6.309^{*} \\
(2.811)\end{array}$ & $\begin{array}{l}8.089^{*} \\
(3.241)\end{array}$ \\
\hline Sample mean DV & & $\begin{array}{l}0.742^{* * *} \\
(0.152)\end{array}$ & & $\begin{array}{l}0.638^{* *} \\
(0.199)\end{array}$ & & $\begin{array}{l}0.479^{* *} \\
(0.157)\end{array}$ \\
\hline $\begin{array}{l}\text { Debt stock (mo. of } \\
\text { Exports, } \ln )\end{array}$ & & $\begin{array}{c}-0.000560^{* * *} \\
(0.000164)\end{array}$ & & $\begin{array}{c}-0.000429 \\
(0.000277)\end{array}$ & & $\begin{array}{c}-0.00164^{*} \\
(0.000826)\end{array}$ \\
\hline GDP per capita $(\ln )$ & & $\begin{array}{l}-1.107^{* *} \\
(0.338)\end{array}$ & & $\begin{array}{l}-1.708^{* *} \\
(0.571)\end{array}$ & & $\begin{array}{r}-3.183^{\dagger} \\
(1.706)\end{array}$ \\
\hline Democracy & & $\begin{array}{c}-0.0504^{* *} \\
(0.0182)\end{array}$ & & $\begin{array}{r}0.0592^{\dagger} \\
(0.0306)\end{array}$ & & $\begin{array}{l}0.149 \\
(0.0910)\end{array}$ \\
\hline $\begin{array}{l}\text { Count of ongoing } \\
\text { conflicts (dyads) }\end{array}$ & & $\begin{array}{l}0.384^{* *} \\
(0.124)\end{array}$ & & $\begin{array}{c}-0.0444 \\
(0.212)\end{array}$ & & $\begin{array}{c}-1.876^{* *} \\
(0.627)\end{array}$ \\
\hline Conflict end & & $\begin{array}{l}-0.447^{* * *} \\
(0.132)\end{array}$ & & $\begin{array}{c}-0.0409 \\
(0.227)\end{array}$ & & $\begin{array}{l}1.389^{*} \\
(0.669)\end{array}$ \\
\hline $\begin{array}{l}\text { Conflict duration } \\
\text { (maximum) }\end{array}$ & & $\begin{array}{c}-0.0178^{\dagger} \\
(0.00966)\end{array}$ & & $\begin{array}{r}0.0350^{*} \\
(0.0163)\end{array}$ & & $\begin{array}{c}-0.0598 \\
(0.0485)\end{array}$ \\
\hline $\begin{array}{l}\text { Conflict intensity } \\
\text { (maximum) }\end{array}$ & & $\begin{array}{c}-0.0844 \\
(0.168)\end{array}$ & & $\begin{array}{r}-0.528^{\dagger} \\
(0.284)\end{array}$ & & $\begin{array}{c}-1.828^{*} \\
(0.844)\end{array}$ \\
\hline Constant & $\begin{array}{l}6.138^{* * *} \\
(0.258)\end{array}$ & $\begin{array}{l}10.46^{* * *} \\
(2.486)\end{array}$ & $\begin{array}{l}2.191^{* * *} \\
(0.416)\end{array}$ & $\begin{array}{r}13.19^{* *} \\
(4.025)\end{array}$ & $\begin{array}{l}17.05^{* * *} \\
(1.348)\end{array}$ & $\begin{array}{l}38.59^{* *} \\
(12.49)\end{array}$ \\
\hline Observations & 811 & 618 & 811 & 618 & 810 & 617 \\
\hline Countries & 70 & 61 & 70 & 61 & 70 & 61 \\
\hline Country FE & YES & YES & YES & YES & YES & YES \\
\hline Decade FE & YES & YES & YES & YES & YES & YES \\
\hline R2: Within & 0.122 & 0.316 & 0.0997 & 0.167 & 0.00677 & 0.0958 \\
\hline Between & 0.0167 & 0.188 & 0.0669 & 0.244 & 0.0640 & 0.410 \\
\hline Overall & 0.00738 & 0.0706 & 0.0554 & 0.144 & 0.0138 & 0.311 \\
\hline
\end{tabular}

Statistical significance indicated as follows: ${ }^{* * *} \mathrm{p}<0.001,{ }^{* *} \mathrm{p}<0.01,{ }^{*} \mathrm{p}<0.05,{ }^{\dagger} \mathrm{p}<0.1$.

This is surprising because it suggests that drastic changes in the government's interference on monetary policy do not affect the likelihood of negotiated outcomes, shedding doubts on this association. Finally, $C B I$ does not significantly affect the probability of a rebel victory or of other forms of termination.

In sum, $C B I$ is robustly associated with a substantial increase in the probability of a war ending in a government victory. In some models, it is associated with a larger predicted probability of negotiated termination, but this result is not robust. Finally, $C B I$ does not seem to affect the likelihood of other forms of termination.

\section{On the possible mechanism}

I argue that central bank independence enhances the ability of governments to end civil wars because it is a good signal in international markets (Gray, 2013; Bodea $\&$ Hicks, 2015a). In particular, I argue that central bank independence signals the ability of the country to repay debt, and the government's commitment to economic orthodoxy (Garriga \& Meseguer, 2019) - that may also affect the ability to repay. This should allow countries that are experiencing civil wars but who have independent central banks to have better access to international credit. In this section, I test the plausibility of this mechanism.

Hypothesis 3 states that central bank independence is associated with better conditions in international credit markets. I proxy access to credit markets using three variables: average interest rate (Interest rate), average grace period in years (Grace period), and average maturity in years (Debt maturity) of new external debt commitments. ${ }^{18}$

\footnotetext{
${ }^{18}$ Credit ratings also could proxy access to private lenders. However, the three proxies for access to capital used here directly measure the conditions of credit that are effectively available to countries from either private sources or international financial institutions. The use
} 
Data are from the World Bank. ${ }^{19}$ I control for debt stock (in months of exports, logged), log of GDP per capita, regime type (using Polity2), sample average of the dependent variable to account for the market conditions in a given year, ${ }^{20}$ number of ongoing civil conflicts the government is fighting in a given year, whether the conflict ended in a given year, the maximum duration and the average or maximum intensity of ongoing conflict(s). In these models, the unit of analysis is country-year. I estimate regressions with country and decade fixed effects on the sample of countries experiencing civil wars.

Results in Table III and in Online appendix 6 show support for this hypothesis. In countries with more independent central banks than countries with dependent banks, and where they are experiencing civil wars, new debt commitments have lower interest rates, and longer grace and maturity periods. Substantively, in models including all controls and holding other variables constant, a standard deviation increase in $C B I(0.181)$ is associated with a reduction of 0.5 percentage points in interest rate ( $16 \%$ of the sample mean interest rate), and with 1.06 and 1.38-year increases in the new debt commitments' grace period and loan maturity, respectively. ${ }^{21}$

Additionally, I posit that by controlling inflation, more independent central banks could curb the negative consequences of inflation that could potentially push citizens to oppose the government (Grossman, 1991, 1995; Kriner, Lechase \& Cappella Zielinski, 2015). Hypothesis 4 tests the effect of $C B I$ on inflation in countries experiencing civil wars. I measure inflation as the log of the average monthly change in the consumer price index (International Monetary Fund, 2018). Models include Peg, a dichotomous variable indicating a fixed

of credit ratings is further complicated for the lack of freely available time series with sufficient coverage. However, there is research showing that central bank independence is associated with better risk ratings (Bodea $\&$ Hicks, 2018).

${ }^{19}$ According to the World Bank's definitions, maturity counts the years to original maturity date (grace plus repayment periods). Grace period counts years since the signature of the loan or issue of the financial instrument to first repayment of principal. Repayment period runs from the first to last repayment of principal. Data average all public and publicly guaranteed loans, weighted by the amounts of the loans (https://data.worldbank.org/indicator/ DT.MAT.OFFT? view=chart accessed 1 March 2019).

${ }^{20}$ This captures the effect of other factors not included in the model that may affect worldwide credit availability, and thus, the interest rate, grace and maturity periods of new debt commitments.

${ }^{21}$ The civil war-sample mean for debt interest, grace period, and deb maturity are $3.205 \%, 5.44$ and 18.72 years, respectively.
Table IV. Effect of $C B I$ on inflation in civil war countries

\begin{tabular}{|c|c|c|c|}
\hline & (1) & (2) & (3) \\
\hline$C B I$ & $\begin{array}{c}-3.249^{*} \\
(1.263)\end{array}$ & $\begin{array}{c}-1.754^{* *} \\
(0.557)\end{array}$ & $\begin{array}{c}-1.742^{* *} \\
(0.558)\end{array}$ \\
\hline Polity2 & & $\begin{array}{r}-0.0413^{\dagger} \\
(0.0222)\end{array}$ & $\begin{array}{r}-0.0400^{\dagger} \\
(0.0233)\end{array}$ \\
\hline$C B I^{*}$ Polity 2 & & $\begin{array}{c}0.104^{*} \\
(0.0478)\end{array}$ & $\begin{array}{c}0.102^{*} \\
(0.0499)\end{array}$ \\
\hline Inflation $(\ln )_{t-1}$ & & $\begin{array}{l}0.290^{*} \\
(0.113)\end{array}$ & $\begin{array}{l}0.290^{*} \\
(0.112)\end{array}$ \\
\hline GDP per capita $(\ln )_{t-1}$ & & $\begin{array}{c}0.440^{*} \\
(0.214)\end{array}$ & $\begin{array}{c}0.439^{\dagger} \\
(0.218)\end{array}$ \\
\hline Trade openness $\mathrm{t}_{\mathrm{t}-1}$ & & $\begin{array}{l}0.00145 \\
(0.00409)\end{array}$ & $\begin{array}{c}0.00159 \\
(0.00411)\end{array}$ \\
\hline Peg & & $\begin{array}{c}-0.00681 \\
(0.184)\end{array}$ & $\begin{array}{c}-0.00861 \\
(0.183)\end{array}$ \\
\hline World inflation $_{\mathrm{t}-1}$ & & $\begin{array}{c}0.0654^{\dagger} \\
(0.0368)\end{array}$ & $\begin{array}{c}0.0698^{\dagger} \\
(0.0364)\end{array}$ \\
\hline Fiscal balance $_{\mathrm{t}-1}$ & & $\begin{array}{c}-0.0578^{* * *} \\
(0.0163)\end{array}$ & $\begin{array}{l}-0.0579^{* * *} \\
(0.0163)\end{array}$ \\
\hline $\begin{array}{l}\text { Count of ongoing } \\
\text { conflicts (dyads) }\end{array}$ & & & $\begin{array}{c}-0.0422 \\
(0.0521)\end{array}$ \\
\hline Conflict end & & & $\begin{array}{c}0.0571 \\
(0.0519)\end{array}$ \\
\hline Constant & $\begin{array}{l}3.983^{* * *} \\
(0.581)\end{array}$ & $\begin{array}{l}-1.175 \\
(1.226)\end{array}$ & $\begin{array}{l}-1.215 \\
(1.265)\end{array}$ \\
\hline Observations & 713 & 318 & 318 \\
\hline Countries & 67 & 47 & 47 \\
\hline Country FE & YES & YES & YES \\
\hline Decade FE & $\mathrm{NO}$ & YES & YES \\
\hline R2: Within & 0.090 & 0.373 & 0.374 \\
\hline Between & 0.091 & 0.190 & 0.185 \\
\hline Overall & 0.028 & 0.272 & 0.268 \\
\hline
\end{tabular}

Statistical significance indicated as follows: ${ }^{* * *} \mathrm{p}<0.001$, ${ }^{* *} \mathrm{p}<0.01$, ${ }^{*} \mathrm{p}<0.05,{ }^{\dagger} \mathrm{p}<0.1$. Robust standard errors in parentheses.

exchange rate, ${ }^{22}$ Real GDP per capita, Trade openness (exports plus imports, over GDP), Fiscal balance, and World inflation. Data from the World Bank (2018). I include Polity2 (Marshall \& Jaggers, 2012) both as a control and interacted with CBI (Bodea \& Hicks, 2015a; Garriga \& Rodriguez, 2020).

Results in Table IV show that CBI has a negative and statistically significant coefficient in models without controls, with Polity as control and as interactive term, and after including conflict related controls. This suggests that even in non-democratic countries experiencing civil war, central

\footnotetext{
${ }^{22}$ Peg equals 1 when there is no separate legal tender, when there is a pre-announced peg or currency board arrangement, when there is a pre-announced horizontal band $\leq+/-2 \%$, or when there is a de facto peg. Data from Reinhart \& Rogoff (2009).
} 


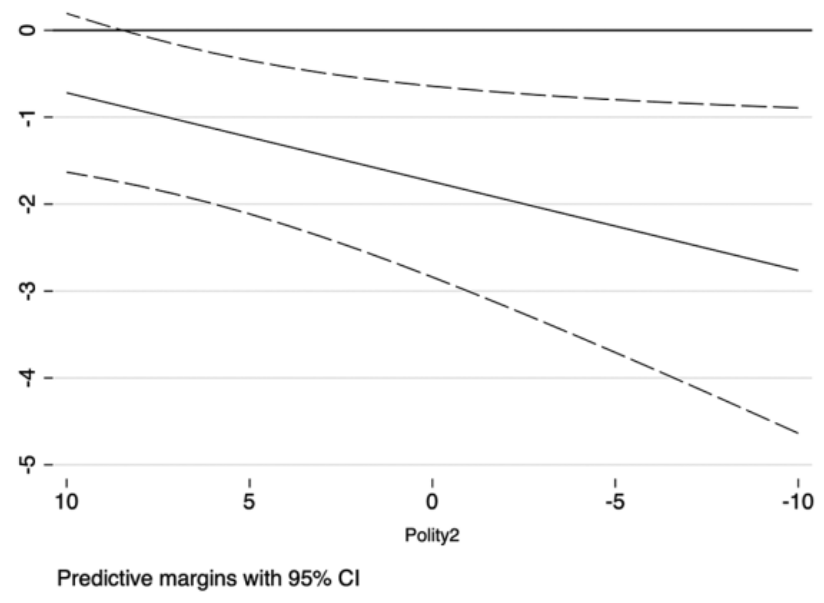

Figure 7. Effect of $C B I$ on inflation at different levels of Polity2 (after model (3))

bank independence is associated with lower inflation. This effect is larger in more democratic countries (see Figure 7).

Inflation is normally not included in models of civil war onset or intensity. I further test whether inflation is associated with a lower probability of civil war onset. I follow Cunningham (2016) and test the effect of two measures of inflation (the natural log and inflation crises) on civil war onset measured in two different ways: onset of internal armed conflicts, and 1,000-battle-death civil wars (Online appendix 7). These results show a positive and generally significant relationship between inflation and civil war onset. ${ }^{23}$

\section{Conclusions}

This article explores an understudied area of conflict finance: the effects of monetary institutions on civil war dynamics. I find that independent central banks are associated with a substantial increase in the likelihood of war termination. This result is robust to different estimation techniques, to the inclusion of different controls, and to changes in the measurement of central bank independence. When I disaggregate the form of termination, central bank independence is associated with a higher probability of government victory relative to continued conflict and to other civil war outcomes. Central bank independence does not significantly affect the likelihood of other forms of war termination. ${ }^{24}$

The evidence supports the idea that central bank independence enhances the ability of governments to end

\footnotetext{
${ }^{23}$ I thank the editor for suggesting these additional analyses.

${ }^{24}$ The association between CBI and negotiated outcomes is not robust.
}

civil wars because it is a good signal in international markets, and because it curbs inflation. In countries experiencing civil wars, governments with more independent central banks contract new debt in better conditions: they receive loans at lower interest rates, and longer grace and maturity periods than countries with dependent central banks. Furthermore, central bank independence has inflation curbing effects in civil war countries, which provides additional support for the proposed mechanisms.

Support for my main hypotheses does not mean that a tying-hands mechanism - that is, independent central banks limit the ability of the government to use inflation or fiscal resources to finance civil war efforts - is not at work. However, even if present, hands-tying does not seem to outweigh the other two mechanisms. In fact, I argue that the better access conditions to international credit markets and the reduced incentives to join rebel forces when there is less inflation are largely due to these constraints that independent central banks place on governments. However, one important contribution of this article is showing that potential negative effects of fiscal constraints on the ability to fight and win civil wars can be outweighed with access to credit and with the positive effects of lower inflation on grievances.

These findings complement research on rebel funding. Future research could investigate likely relations between rebel and government funding in an integrated framework. Additionally, they contribute to a recent literature suggesting that, during conflicts, international capital may free governments from their domestic economic constraints, allowing them to fight rebel opposition while delivering services to the population (DiGiuseppe, Barry \& Frank, 2012; Shea, 2014; Poast, 2015; Cappella Zielinski, 2016; DiGiuseppe \& Shea, 2016). This article, however, focuses on what policies or domestic institutions governments can enact in order to improve their access to international markets. Future research should look at how other ways states fund civil wars affect wars' dynamics and outcomes. Overall, monetary institutions seem to have important effects on civil war termination, and government victory in particular. This suggests that scholars and policymakers alike should expand the framework for analysis of civil war finance. Similarly, this opens further questions on the non-economic consequences of monetary institutions.

\section{Acknowledgements}

I thank the editor and two anonymous reviewers for their comments and suggestions. This research was presented 
at the Conference on Money and Politics (University of California, Irvine, 2018), 2019 EPSA Annual Conference, 2019 ISA Annual Convention, at Universidad Torcuato Di Tella, and City University of London. I thank the participants in these events, Matt DiGiuseppe, Brian Phillips, and Pablo Pinto for their comments, and Giovanna Rodríguez and Tatiana Gelvez for their research assistance.

\section{Replication data}

The dataset and do-files for the empirical analysis in this article are available at https:/www.prio.org/jpr/datasets/ and https://sites.google.com/site/carogarriga/. All analyses were conducted using Stata16.

\section{ORCID iD}

Ana Carolina Garriga (D) https://orcid.org/0000-00029332-8202

\section{References}

Alesina, Alberto \& Lawrence H Summers (1993) Central bank independence and macroeconomic performance: Some comparative evidence. Journal of Money, Credit, and Banking 25(2): 151-163.

Andersen, Per Kragh; John P Klein, Kim M Knudsen \& René Tabanera y Palacios (1997) Estimation of variance in Cox's regression model with shared gamma frailties. Biometrics 53(4): 1475-1484.

Armstrong, Martin (2012) List of modern sovereign debt defaults or debt restructuring (https://www.armstrongeco nomics.com/sovereign-debt-crisis/sovereign-debt-defaultsrestructuring/).

Baerg, Nicole Rae; Julia Gray \& Jakob Willisch (2020) Opportunistic, not optimal delegation: The political origins of central bank independence. Comparative Political Studies 54: 956-988.

Bailey, Michael; Anton Strezhnev \& Erik Voeten (2017) Estimating dynamic state preferences from United Nations voting data. Journal of Conflict Resolution 61(2): 430-456.

Ballentine, Karen \& Jake Sherman (2003) The Political Economy of Armed Conflict: Beyond Greed and Grievance. Boulder, CO: Lynne Rienner Publishers.

Banks, Arthur \& Kenneth Wilson (2016) Cross-National Time-Series Data Archive. Jerusalem, Israel (https://www. cntsdata.com/).

Bodea, Cristina \& Raymond Hicks (2015a) Price stability and central bank independence: Discipline, credibility, and democratic institutions. International Organization 69(1): 35-61.

Bodea, Cristina \& Raymond Hicks (2015b) International finance and central bank independence: Institutional diffusion and the flow and cost of capital. Journal of Politics 77(1): 268-284.

Bodea, Cristina \& Raymond Hicks (2018) Sovereign credit ratings and central banks: Why do analysts pay attention to institutions? Economics \& Politics 30(3): 340-365.

Bodea, Cristina \& Masaaki Higashijima (2017) Central bank independence and fiscal policy: Can the Central bank restrain deficit spending? British Journal of Political Science 47(1): 47-70.

Bodea, Cristina; Ana Carolina Garriga \& Masaaki Higashijima (2019) Economic institutions and autocratic breakdown: Monetary constraints and fiscal spending in dominant-party regimes. The Journal of Politics 81(2): 601-615.

Bordo, Michael \& Hugh Rockoff (1996) The Gold Standard as a 'good housekeeping seal of approval'. The Journal of Economic History 56(2): 389-428.

Bordo, Michael \& Eugene White (2009) A tale of two currencies: British and French finance during the Napoleonic Wars. The Journal of Economic History 51(2): 303-316.

Brownbridge, Martin (1998) Financial repression and financial reform in Uganda. In: Martin Brownbridge, Charles Harvey \& Augustine Fritz Gockel (eds) Banking in Africa: The Impact of Financial Sector Reform since Independence. Oxford: James Currey; Africa World Press, 127-142.

Broz, J Lawrence (1998) The origins of central banking: Solutions to the free-rider problem. International Organization 52(2): 231-268.

Broz, J Lawrence \& Richard S Grossman (2004) Paying for privilege: The political economy of Bank of England charters, 1694-1844. Explorations in Economic History 41(1): 48-72.

Buhaug, Halvard (2006) Relative capability and rebel objective in civil war. Journal of Peace Research 43(6): 691-708.

Cappella Zielinski, Rosella (2016) How States Pay for Wars. Ithaca, NY: Cornell University Press.

Carter, Jeff \& Glenn Palmer (2016) Regime type and interstate war finance. Foreign Policy Analysis 12(4): 695-719.

Clark, William Roberts; Sona N Golder \& Paul Poast (2013) Monetary institutions and the political survival of democratic leaders. International Studies Quarterly 57(3): 556-567.

Collier, Paul; Anke Hoeffler \& Dominic Rohner (2009) Beyond greed and grievance: Feasibility and civil war. Oxford Economic Papers 61(1): 1-27.

Cook, Scott J; Jude C Hays \& Robert J Franzese (2020) Fixed effects in rare events data: A penalized maximum likelihood solution. Political Science Research and Methods 8(1): 92-105.

Cukierman, Alex (1992) Central Bank Strategy, Credibility and Independence: Theory and Evidence. Cambridge, MA: The MIT Press.

Cunningham, David E (2016) Preventing civil war: How the potential for international intervention can deter conflict onset. World Politics 68(2): 307-340. 
Dafe, Florence (2012) The politics of central banking and implications for regulatory reform in Sub-Saharan Africa: The cases of Kenya, Nigeria and Uganda. German Development Institute/Deutsches Institut Für Entwicklungspolitik (DIE) Discussion Paper 2.

DiGiuseppe, Matthew (2015a) The fiscal autonomy of deciders: Creditworthiness and conflict initiation. Foreign Policy Analysis 11(3): 317-338.

DiGiuseppe, Matthew (2015b) Guns, butter, and debt: Sovereign creditworthiness and military expenditure. Journal of Peace Research 52(5): 680-693.

DiGiuseppe, Matthew \& Patrick Shea (2016) Borrowed time: Sovereign finance, regime type, and leader survival. Economics \& Politics 28(3): 342-367.

DiGiuseppe, Matthew; Colin Barry \& Richard W Frank (2012) Good for the money: International finance, state capacity, and internal armed conflict. Journal of Peace Research 49(3): 391-405.

Easterly, William \& Stanley Fischer (2001) Inflation and the poor. Journal of Money, Credit and Banking 33(2): 160-178.

Escribà-Folch, Abel (2010) Economic sanctions and the duration of civil conflicts. Journal of Peace Research 47(2): 129-141.

Fearon, James D (2004) Why do some civil wars last so much longer than others? Journal of Peace Research 41(3): 275-301.

Fielding, David \& Anja Shortland (2012) The dynamics of terror during the Peruvian civil war. Journal of Peace Research 49(6): 847-862.

Flandreau, Marc \& Juan H Flores (2012) The peaceful conspiracy: Bond markets and international relations during the Pax Britannica. International Organization 66(2): 211-241.

Garriga, Ana Carolina (2016) Central bank independence in the world: A new data set. International Interactions 42(5): 849-868.

Garriga, Ana Carolina \& Covadonga Meseguer (2019) Remittances, monetary institutions, and autocracies. Oxford Development Studies 47(4): 452-467.

Garriga, Ana Carolina \& Cesar M Rodriguez (2020) More effective than we thought: Central bank independence and inflation in developing countries. Economic Modelling 85(1): 87-105.

Gray, Julia (2013) The Company States Keep: International Economic Organizations and Investor Perceptions in Emerging Markets. New York: Cambridge University Press.

Grossman, Herschell (1991) A general equilibrium model of insurrections. The American Economic Review 81(4): 912-921.

Grossman, Herschell (1995) Insurrections. In: Keith Hartley \& Todd Sandler (eds) Handbook of Defense Economics Vol. 1. Amsterdam: Elsevier, 191-212.
Grossman, Herschel \& Taejoon Han (1996) War debt, moral hazard, and the financing of the confederacy. Journal of Money, Credit and Banking 28(2): 200-215.

Hamilton, Earl J (1977) The role of war in modern inflation. The Journal of Economic History 37(1): 13-19.

Hendrix, Cullen S (2010) Measuring state capacity: Theoretical and empirical implications for the study of civil conflict. Journal of Peace Research 47(3): 273-285.

Hendrix, Cullen S \& Joseph Young (2014) State capacity and terrorism: A two-dimensional approach. Security Studies 23(2): 329-363.

Högbladh, Stina; Therése Pettersson \& Lotta Themnér (2011) External support in armed conflict 1975-2009. Presenting new data. Presented at the International Studies Association Convention. Montreal (https://ucdp.uu.se/ downloads/index.html\#externalsupport).

International Monetary Fund (2018) International financial statistics (https://data.imf.org/?sk=4C514D48-B6BA49ED-8AB9-52B0C1A0179B\&sId=1390030341854).

Kang, Seonjou \& James Meernik (2005) Civil war destruction and the prospects for economic growth. The Journal of Politics 67(1): 88-109.

Keen, David (2005) Liberalization and conflict. International Political Science Review 26(1): 73-89.

Kirkpatrick, David (2015) Fighters capture a branch of Libya's central bank. The New York Times 23 January: A9.

Kirshner, Jonathan (2007) Appeasing Bankers: Financial Caution on the Road to War. Princeton, NJ: Princeton University Press.

Koren, Ore \& Benjamin Bagozzi (2017) Living off the land: The connection between cropland, food security, and violence against civilians. Journal of Peace Research 54(3): 351-364.

Kreutz, Joakim (2010) How and when armed conflicts end: Introducing the conflict termination dataset. Journal of Peace Research 47(2): 243-250.

Kriner, Douglas; Breanna Lechase \& Rosella Cappella Zielinski (2015) Self-interest, partisanship, and the conditional influence of taxation on support for war in the USA. Conflict Management and Peace Science 35(1): 43-64.

Licht, Amanda A (2011) Change comes with time: Substantive interpretation of nonproportional hazards in event history analysis. Political Analysis 19(2): 227-243.

Lujala, Päivi (2010) The spoils of nature: Armed civil conflict and rebel access to natural resources. Journal of Peace Research 47(1): 15-28.

Marshall, Monty G \& Keith Jaggers (2012) Polity IV dataset (https://www.systemicpeace.org/polityproject.html).

Maxfield, Sylvia (1997) Gatekeepers of Growth: The International Political Economy of Central Banking in Developing Countries. Princeton, NJ: Princeton University Press.

Narang, Neil (2015) Assisting uncertainty: How humanitarian aid can inadvertently prolong civil war. International Studies Quarterly 59(1): 184-195. 
Neyapti, Bilin (2001) Central bank independence and economic performance in Eastern Europe. Economic Systems 25(4): 381-399.

Neyapti, Bilin (2003) Budget deficits and inflation: The roles of central bank independence and financial market development. Contemporary Economic Policy 21(4): 458-475.

Pastor, Manuel Jr., \& Sylvia Maxfield (1999) Central bank independence and private investment in the developing world. Economics \& Politics 11(3): 299-309.

Poast, Paul (2015) Central banks at war. International Organization 69(1): 63-95.

Polillo, Simone \& Mauro F Guillén (2005) Globalization pressures and the state: The global spread of central bank independence. American Journal of Sociology 110(6): 1764-1802.

Regan, Patrick M (2002) Third-party interventions and the duration of intrastate conflicts. Journal of Conflict Resolution 46(1): 55-73.

Reinhart, Carmen M \& Kenneth S Rogoff (2009) This Time Is Different: Eight Centuries of Financial Folly. Princeton, NJ: Princeton University Press.

Rey, Hélène (2015) Dilemma Not Trilemma: The Global Financial Cycle and Monetary Policy Independence. Cambridge, MA: National Bureau of Economic Research.

Sawyer, Katherine; Kathleen Gallagher Cunningham \& William Reed (2017) The role of external support in civil war termination. Journal of Conflict Resolution 61(6): 1174-1202.

Seligman, Edwin RA (1918) Loans versus taxes in war finance. The ANNALS of the American Academy of Political and Social Science 75(1): 52-82.

Shea, Patrick (2014) Financing victory. Journal of Conflict Resolution 58(5): 771-795.
Shea, Patrick (2016) Borrowing trouble: Sovereign credit, military regimes, and conflict. International Interactions 42(3): 401-428.

Shea, Patrick \& Paul Poast (2017) War and default. Journal of Conflict Resolution 62(9): 1876-1904.

Slantchev, Branislav L (2012) Borrowed power: Debt finance and the resort to arms. American Political Science Review 106(4): 787-809.

Weidenmier, Marc D (2005) Gunboats, reputation, and sovereign repayment: Lessons from the Southern Confederacy. Journal of International Economics 66(2): 407-422.

Weinstein, Jeremy M (2005) Resources and the information problem in rebel recruitment. Journal of Conflict Resolution 49(4): 598-624.

Whitaker, Beth Elise; James Igoe Walsh \& Justin Conrad (2019) Natural resource exploitation and sexual violence by rebel groups. The Journal of Politics 81(2): 702-706.

World Bank (2018) World development indicators on-line (https://datacatalog.worldbank.org/dataset/world-develop ment-indicators).

ANA CAROLINA GARRIGA, b. 1974, PhD in Political Science (University of Pittsburgh, 2010). Reader, University of Essex (2018- ), and Affiliated Professor, CIDE. Current main interests: central banks, foreign direct investment, political economy of conflict. Recent articles in Journal of Politics, International Studies Quarterly, Journal of Conflict Resolution, Regulation \& Governance, International Interactions, Economic Modelling, and other outlets. 